\title{
2401 流動層における炭酸カルシウムの熱分解
}

$\begin{array}{rrrrl}\text { 京都大学工学部教授・工博 } & \text { 近 } & \text { 藤 } & \text { 良 } & \text { 夫(正会員) } \\ \text { 京都大学工学部助手 } & \bigcirc \text { 朝 } & \text { 善 次 } & \text { 郎(正会員) } \\ \text { 京都大学工学部大学院学生 } & \text { 長 } & \text { 瀬 隆 } & \text { 夫 }\end{array}$

\section{1. 緒 言}

$\mathrm{CaCO}_{3}$ の熱分解反応は $\mathrm{CaCO}_{3} \rightarrow \mathrm{CaO}+\mathrm{CO}_{2}$ で示され， 約 $40 \mathrm{kcal} / \mathrm{mol}$ の吸熱を伴なう。一般飞固体の熱分解 反応は主としてつきの 3 つの過程からなると考克られる。

1）外部から粒子の反応界面への熱の移動

2）熱分解反応

3）反応界面から外部への気体反応生成物の移動 これらのらち、いずれが総括反応速度を律速するかは, 反応飞関与する物質の性質扣よび反応条件によって異な るが, $\mathrm{CaCO}_{3}$ の熱分解の上うに, その吸熱量がきく, かつ反応生成物である $\mathrm{CaO}$ が多孔質であり，また 2)の 段階が比較的速やかである場合飞は, いわゆる层熱律速 の形式をとることが多(11)・2) 3)。一方, 流動層では層内 の有効伝熱係数が一般に大きいため, 首内の温度分布は 極めて均一になる。このことはまた多量の熱の授受を伴 な5反応に対して, 流動首が好都合であることを示して いる。ここでは, 回分法流動層に括ける $\mathrm{CaCO}_{3}$ 粒子の熱 分解反応について速度論に検討を加光ることとした。

\section{2. 試料およひ実験装置}

本研究に用いた試料は宇部興産株式会社より送付を5 けた塊状の石灰石で，これをショークラッシャおよび クラッシングロールにより 60 100 mesh 飞粉啸, ふる い分けした。本試料の 1150 C 亿抢ける灼熱減量率は $44.0 \%$ ある。

実験装置の、概略を第 1 図に示す。流動反応管は内径 45 $\mathrm{mm}$ の石英管で, 流動首下部は頂角 $30^{\circ}$ の円錐形とし, この頂部に直径 $4.8 \mathrm{~mm}$ の鋼球を扰き, 空気の整流と流動 首の支持を行なった。な拈, 反応管下端にニク口ム抵抗 線を扣き，送入空気を予熱した。実験に際して，まず所 定量の空気を送入した状態で反応管内を設定温度飞保っ た後, $150 \mathrm{~g}$ の石灰石を反応管上部より投入し, 分解反応 を進行させた。反応途上飞扔いて, 首温度 $t_{f}$, 壁温度 $t_{w}$, ガス温度 $t_{g}$ を測定するとともに, 外径 $10 \mathrm{~mm}$ の石 英管製のサンプラーを用いて, 約 $1 \mathrm{~g}$ の試料を $5 \sim 10$ 回 採取した。

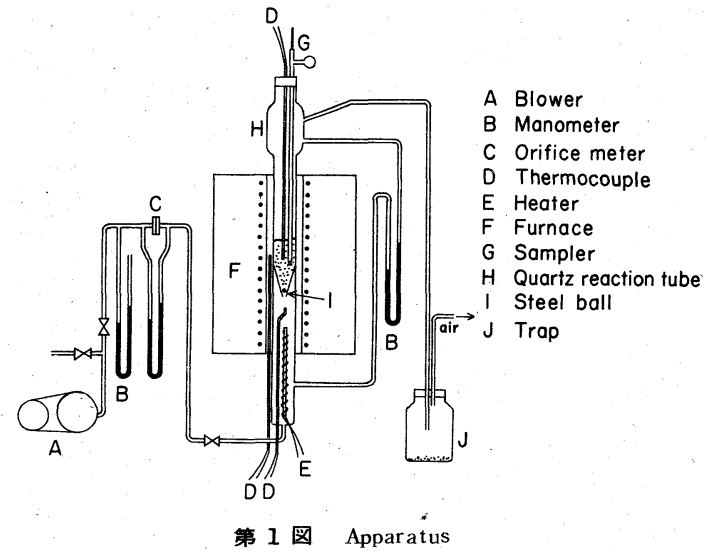

流動化条件として，設定温度および空気流速をとれぞ れつぎに示す 3 水準に選び，これらの 9 通りの組合せ条 件で実験を行なった。

設定温度： $825,850,875 \mathrm{C}$

空気流速： $19,28,46 \mathrm{cc} / \mathrm{sec}$

\section{3. 反応速度式}

首温度 $t_{f}$ は, 第 2 図飞示すよ 5 亿, 試料の投入と同時 飞急激に低下するが, 間むなく回復し, 設定温度よりや や低い一定の值 $t_{z}$ を示し, 反応が終了するまでこの温度 を保つ。この段階に打ける反応速度式を求めるため, 第 2 四のモデルを仮定する。すなわら

1）温度 $t_{w}$ 亿保たれる壁からの伝熱量 $q$ は，すへてて粒 子飞供給される。

2）粒子とガスとの間の熱の授受堂無視する。

3）全粒子は分解温度 $t_{d}$ 江加熱され，平均として半径 $\bar{r}$ の位置飞反応界面をるつ。また熱分解生成物 $\mathrm{CaO}$ 拈よ び $\mathrm{CO}_{2}$ は $t_{d}$ から $t_{f}$ まで加熱される。

この反応が卮熱律速であるとすると

$q=(d W / d \theta) \Delta H_{T}$

が成立する。ここに $d W$ は時間 $d \theta$ 内に分解する $\mathrm{CaCO}_{3}$ の重量， $\Delta H_{T}$ はそのエンタルピー变化を示す。この备項 はつぎの式で表わされる。

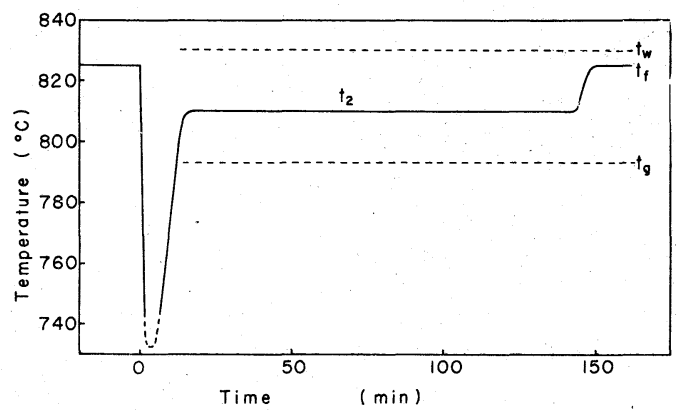

第2図 An example of bed,wall and gas temperatures during thermal decomposition (Flow rate of air 28 $\mathrm{cc} / \mathrm{sec}$, Temperature $825^{\circ} \mathrm{C}$ )

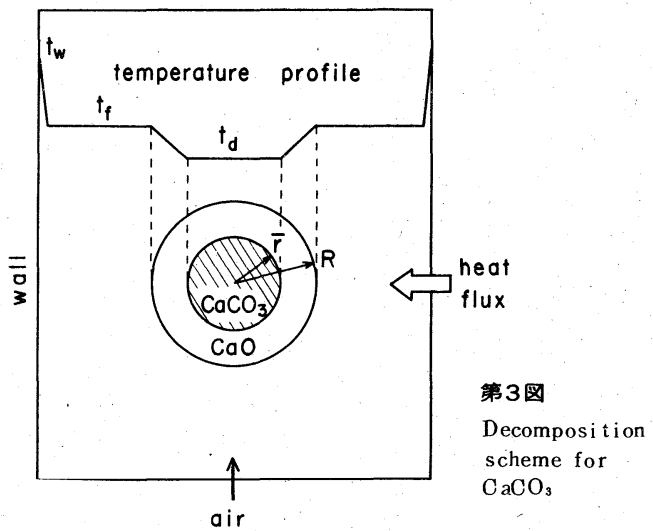

日 本鉱業会誌 


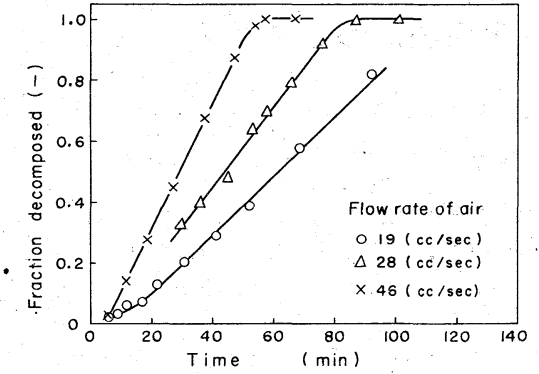

第4図 An example of fraction decomposed (Temperature $850^{\circ} \mathrm{C}$ )

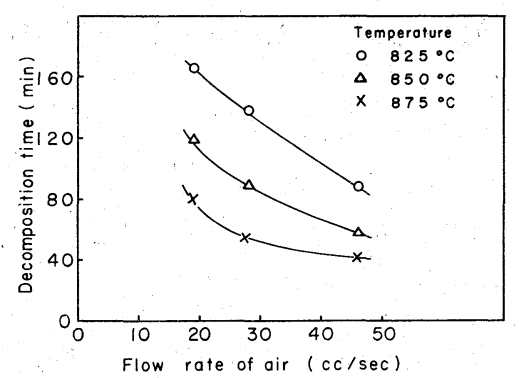

第5図 Relationship between flow rate of ai $r$ and decomposition time

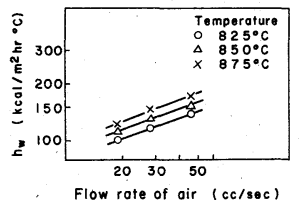

第6 図

Relat ionship between flow rate of ai $r$ and heat $t$ ransfer coefficie$\mathrm{nt} h w$

$$
\begin{gathered}
q=\pi D_{f} L_{f} h_{w}\left(t_{w}-t_{f}\right)=4 \pi R \bar{r} N k_{e} \frac{t_{f}-t_{d}}{R-\bar{r}} \\
=\frac{\pi D_{f} L_{f}\left(t_{w}-t_{d}\right)}{\frac{1}{h_{w}}+\frac{4 R^{2}(R-\bar{r})}{3 D_{f} \bar{r}(1-\varepsilon) k_{e}}} \\
\frac{d W}{d \theta}=-4 \pi \rho \bar{r}^{2} N \frac{d \bar{r}}{d \theta} \\
=-\frac{3 \pi \rho \bar{r}^{2} D^{2} L_{f}(1-\varepsilon)}{4 R^{3}} \frac{d \bar{r}}{d \theta} \\
\Delta H_{T}=\Delta H_{t d}+\frac{M_{\mathrm{CaO}}}{M_{\mathrm{CaCO}_{3}}} \int_{t_{d}}^{t_{f}} C_{\mathrm{CaO}} d t \\
\quad+\frac{M_{\mathrm{CO}_{2}}}{M_{\mathrm{CaCO}_{3}} \int_{t_{d}}^{t_{f}} C_{\mathrm{CO}_{2}} d t}
\end{gathered}
$$

たたし， $D_{f}$ : 流動管内径, $L_{f}$ : 流動層高さ, $h_{w}$ : 壁一層 間総括伝熱係数, $R$ : 粒子半径, $k_{e}: \mathrm{CaO}$ 層の有効熱伝 導度, $\varepsilon$ : 空隙率, $\rho: \mathrm{CaCO}_{3}$ の密度, $N$ : 流動層内の 全粒子数

さらに, 分解率 $x$ 亿ついて $\bar{r}=R(1-x)^{\frac{1}{8}}$ が成立するか ら式 (1)を $x$ の関数として表わすと

$$
\begin{aligned}
\frac{1}{4} \rho D_{f}(1-\varepsilon) \Delta H_{T} \frac{d x}{d \theta} \\
=\frac{t_{w}-t_{d}}{\frac{1}{h_{w}}+\frac{4 R^{2}\left\{1-(1-x)^{\frac{1}{3}}\right\}}{3 D_{f}(1-x)^{\frac{1}{3}}} \frac{(1-\varepsilon) k_{e}}{(1-\varepsilon)}}
\end{aligned}
$$

これを初期条件 $\theta=0 ， x=0$ を用いて解くと

$$
\left.\begin{array}{c}
\frac{1}{4} \rho D_{f}(1-\varepsilon) \Delta H_{T}\left\{\frac{1}{h_{w}}-\frac{4 R^{2}}{3 D_{f}(1-\varepsilon) k_{e}}\right\} x \\
+\frac{\rho R^{2} \Delta H_{T}}{2 k_{e}}\left\{1-(1-x)^{\frac{2}{3}}\right\}=\left(t_{w}-t_{d}\right) \theta
\end{array}\right\}
$$

これが第 3 図に対応する速度式である。粒子内伝熱抵抗 を無視しうる程度に $R$ が小さければ， $t_{d}=t_{z}$ として

$$
\frac{1}{4} \rho D_{f}(1-\varepsilon) \Delta H_{T} x=h_{w}\left(t_{w}-t_{z}\right) \theta
$$

となり，零次反応速度式を得る。

\section{4. 実験結果および考察}

第 4 困に示した設定温度 $850^{\circ} \mathrm{C}$ の場合の測定結果の一

例からわかるよ に増加し, 式 (7) 亿示した零次反応速度式を満足する。 他の設定温度に扣ける測定結果も第 4 図と同じ傾向を示 した。分解所要時間 $\theta_{d}$ は, 第 5 図に示すよ 5 亿, 設定温 度の他に空気流速によって著しく変化する。

第 4 図の直線の勾配を $b$. とすると，これと式 (7)から

$$
h_{w}=\frac{\rho D_{f}(1-\varepsilon) \Delta H_{T} b}{4\left(t_{w}-t_{z}\right)}
$$

となる。これから算出した $h_{w}$ を第 6 図に示す。この結果 を無次元化し, レイノルズ数とヌッセルト数の関係式に 直すと

$$
\begin{aligned}
& \left(h_{w} D_{\boldsymbol{P}} / k_{f}\right)=0.79\left(D_{P} G / \mu_{f}\right)^{0.33}\left(825^{\circ} \mathrm{C}\right) \cdots \cdots(9) \\
& \left(h_{w} D_{\mathbf{P}} / k_{f}\right)=0.87\left(D_{P} G / \mu_{f}\right)^{0.35}\left(850^{\circ} \mathrm{C}\right) \cdots \cdots(10) \\
& \left(h_{w} D_{P} / k_{f}\right)=0.95\left(D_{P} G / \mu_{f}\right){ }^{0.38}\left(875^{\circ} \mathrm{C}\right) \cdots \cdots(11)
\end{aligned}
$$

となる。たたし， $D_{P}$ は粒子径， $G, k_{f}$ 打よび $\mu_{f}$ はそれ ぞれ空気の質量速度, 熟伝導度和よび粘度を示す。一方, Levenspiel とWalton が提出した実験式 ${ }^{4)}$

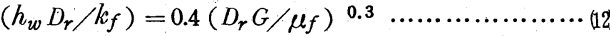

$$
\begin{aligned}
& \text { たすし } D_{r}=\pi D_{P} / 6(1-\varepsilon)
\end{aligned}
$$

を本実験のデータを用いて変形すると

$$
\left(h_{w} D_{P} / k_{f}\right)=0.49\left(D_{P} G / \mu_{f}\right)^{0.3}
$$

となり, 式 (9)〜（11）にかなり一致する。

\section{5. 要 約}

回分法流動首に打ける60-100mesh $\mathrm{CaCO}_{3}$ の熱分 解反応速度について検討を加えた結果, 伝熱律速を仮定 し,さらに粒子内伝熱抵抗を無視して得られる零次反応 速度式を満足した。またその反応速度は設定温度が高い ほど，また空気流速が大きくなる。

$$
\text { 文 }
$$

1) Narsi mhan, G. :Chem. Eng. Sci., 1961, Vol. 11, pp. 7-14

2) Satterfield,C.N. and F.Feakes: A.I.Ch.E.Journal, 1959, Vol.5, pp.115-121

3) Kingery, W.D. : Kinetics of High Temperature Processes, 1959, pp. 294-301, John Wi ley

4) Wal ton, J . S. and O. Levenspiel : Chem. Eng. Progr., Sym. Ses., 1954 , No. 9 